\title{
Structure and diversity of shallow soft-bottom benthic macrofauna in the Gulf of Lions (NW Mediterranean)
}

\author{
Céline Labrune $\cdot$ Antoine Grémare . \\ Jean-Michel Amouroux • Rafael Sardá · \\ João Gil $\cdot$ Sergi Taboada
}

Received: 20 September 2007 / Revised: 6 December 2007 / Accepted: 10 January 2008 / Published online: 15 February 2008

(C) Springer-Verlag and AWI 2008

\begin{abstract}
Samples of soft-sediment macrobenthos from 92 sites between 10 and $50 \mathrm{~m}$ depth were used to assess (1) the main soft-bottom macrofauna communities in the Gulf of Lions, (2) the different components of the diversity of benthic macrofauna in this area, and (3) the relevance of the use of major taxonomic groups as surrogates for the analysis of the structure and diversity of total macrofauna. Three main communities were identified by cluster analysis and associated procedures. These communities corresponded well to the assemblages recently identified on the basis of polychaete composition. The $\alpha$-diversity indices were in accordance with those reported for similar communities in the Mediterranean. Conversely, the $\beta$-diversity value was higher than the few other data available in the literature for marine soft-bottom macrofauna. The total number of species in the studied area estimated by the
\end{abstract}

Communicated by H.-D. Franke.

C. Labrune $\cdot$ J.-M. Amouroux

UPMC Univ Paris 06, UMR7621, Laboratoire d'Océanographie

Biologique de Banyuls, 66650 Banyuls-sur-Mer, France

C. Labrune $(\bowtie) \cdot$ J.-M. Amouroux

CNRS, UMR7621, Laboratoire d'Océanographie Biologique de Banyuls, 66650 Banyuls-sur-Mer, France

e-mail: labrune@obs-banyuls.fr

A. Grémare

Station Biologique d'Arcachon, UMR 5085,

Université Bordeaux 1 - CNRS, 2 rue du Professeur Jolyet,

33120 Arcachon, France

R. Sardá · J. Gil · S. Taboada

Centre d'Estudis Avançats de Blanes, CSIC,

Carrer d'acces a la Cala Sant Francesc, 14,

17300, Blanes, Girona, Spain "total species accumulation curve" (TS) method was 2,319 , which was only $10 \%$ higher than the number obtained by extrapolation of the species-area curve. The similarity matrix based on polychaetes correlated best with the one based on total macrofauna. Polychaetes and crustaceans were also the best surrogates of total macrofauna when assessing $\alpha$-diversity (except in the case of $\Delta^{*}$ ). Conversely, molluscs were the best surrogates of total macrofauna $\beta$-diversity. Our results show that the choice of an optimal surrogate for total benthic macrofauna depends on the characteristic of the benthic macrofauna to be studied. Moreover, this choice is also dependent on the environment to be studied.

Keywords Macrobenthos - Community structure . Surrogates · Diversity · Gulf of Lions

\section{Introduction}

Biodiversity is commonly defined as the variety of life (Gaston and Spicer 1998) from the genomic to the ecosystem scale. There are thus many ways to measure biodiversity and there is no single scale in which it should be measured (Levin 1992). As far as spatial scales and species diversity are concerned, this led to the classic distinction between $\alpha$ (i.e., the diversity of species occurring at a single site) and $\gamma$ (i.e., the diversity of species occurring at the regional scale) diversity (Whittaker 1960). The $\alpha$-diversity accounts both for species richness and dominance (number of species per site). Many indices accounting for different proportions of these two parameters have been proposed to assess $\alpha$-diversity (e.g., Shannon and Weaver 1949; Pielou 1966; Hurlbert 1971). The main difficulty in assessing $\gamma$-diversity is related to 
insufficient sampling. Several estimators (e.g., Chao 1984; Grassle and Maciolek 1992; Karakassis 1995; Gray et al. 1997) as well as several extrapolation techniques (e.g., Ugland et al. 2003, 2005) have been proposed to infer the true number of species present in a given area. However, this problem is far from being solved yet. At last $\beta$-diversity corresponds to the turnover of species along a gradient (or between communities). It is thus of different dimensional character from $\alpha$ and $\gamma$-diversity; $\beta$-diversity is most often assessed through the ratio between $\gamma$-and average $\alpha$ diversity (Whittaker 1972). Measures of $\beta$-diversity are clearly needed to enhance our understanding of the structure of ecosystems, which could have important implications in conservation planning (Levin 1992; Kunin 1997).

In recent years, evaluating the consequences of changes in marine biodiversity due to human activities has become a priority. It is currently agreed that this priority is seriously compromised by inadequate knowledge of the patterns and the basic processes that control the biodiversity in the sea (National Research Council 1995). Soft substrates cover the vast majority of the bottom of the world's ocean. Assessing their biodiversity is thus of special importance. This assessment is however complicated by the difficulty in sampling and sharply delineating habitats in these systems.

Benthic macrofauna corresponds to organisms larger than $1 \mathrm{~mm}$ in size inhabiting marine bottoms. The analysis of macrofauna is essential for assessing diversity patterns in marine soft-bottoms. Soft-bottom macrofauna is structured in communities (groups of tightly associated species), which are largely controlled by abiotic factors (e.g., depth, granulometry). In marine soft-bottoms, disturbance has been shown to initiate a secondary succession process (Pearson and Rosenberg 1978), which is among other things characterized by important changes in the diversity of macrofauna (Rygg 1985; Rosenberg et al. 1987; Bellan and Bourcier 1990; Josefson et al. 1993; Bourcier 1996; Sardá et al. 2000, 2001). Studying the diversity of softbottom macrofauna is thus also of interest in assessing the level of disturbance experienced by marine habitats (Warwick 1988; Olsgard et al. 1997; Dauvin et al. 2003).

The analysis of benthic soft-bottom communities involves long and tedious sorting and identifying procedures (Warwick 1993; Roberts et al. 1998). Two main approaches have been proposed to overcome these difficulties. Taxonomic sufficiency consists in identifying macrofauna at a higher taxonomic level than species and has proved to be efficient in assessing the effects of major disturbances (Warwick 1988, 1993; Warwick and Clarke 1993; Somerfield and Clarke 1995; Gomez Gesteira et al. 2003). Another approach consists in conducting identifications to the species level but only on a restricted number of major taxonomic groups, which are then used as surrogates for total macrofauna (Olsgard et al. 2003; Giangrande et al. 2005). This latter procedure has been most often carried out on polychaetes and molluscs (Belan 2004; Giangrande et al. 2005; Mackie et al. 2005). It aims not only on assessing the effect of disturbance on soft-bottom sediments (Bellan et al. 1988; Gesteira and Dauvin 2000; Belan 2004; Giangrande et al. 2005) but also on assessing the diversity of those bottoms (Olsgard et al. 2003; Mackie et al. 2005). Polychaetes have been shown to constitute a good surrogate for describing species richness (Olsgard et al. 2003) or even the distribution of macrobenthic communities along gradients in disturbed areas (Olsgard and Somerfield 2000). However, the use of surrogates for total macrofauna remains still questionable as several components of the same ecosystem may for example reflect different environmental gradients (Karakassis et al. 2006).

Labrune et al. (2006b, 2007) have recently carried out a detailed analysis of the structure and diversity of polychaete assemblages in the Gulf of Lions (NW Mediterranean) based on an extensive set of 92 sampling sites. Although the Gulf of Lions is one of the best-sampled marine areas within the Mediterranean Sea, these authors pinpointed the lack of sound data regarding the composition and diversity of its soft-bottom marine fauna.

The present study is based on the same set of sampling sites, but considers total macrofauna through two complementary approaches. Considered first is a descriptive approach, which aims at describing benthic macrofauna communities in the Gulf of Lions and the different components of diversity in this area. Such a regional scale data set will provide a first valid reference for the structure and diversity of soft-bottom macrofauna in the Gulf of Lions. Second, a comparative approach aims at relating the results derived from the analysis of total macrofauna with those derived from the analysis of each major taxonomic group. This second approach deals with the possible use of major taxonomic groups as surrogates for the analysis of the structure and diversity of total macrofauna.

\section{Materials and methods}

Collection and processing of sediment samples

Benthic samples were collected in September to October 1998 on N.O. "Georges Petit" along the coast between the Spanish-French border and the mouth of the Rhône River (Fig. 1). This section of coast spans about $110 \mathrm{~km}$ from south to north and $140 \mathrm{~km}$ from west to east. Sampling sites were located on 21 inshore-offshore transects (A-U). Most transects were sampled at 10,20,30, 40 and $50 \mathrm{~m}$ depth. Transects O, P, Q, S and U were only sampled at 10, 20 and 
Fig. 1 Sedimentary map of the Gulf of Lions (after Aloisi et al. 1973) with location of the 92 sites and the spatial distribution of the four main clusters and sub-clusters identified on the basis of the composition of the benthic macrofauna. Letters $A$ to $U$ correspond to the 21 transects

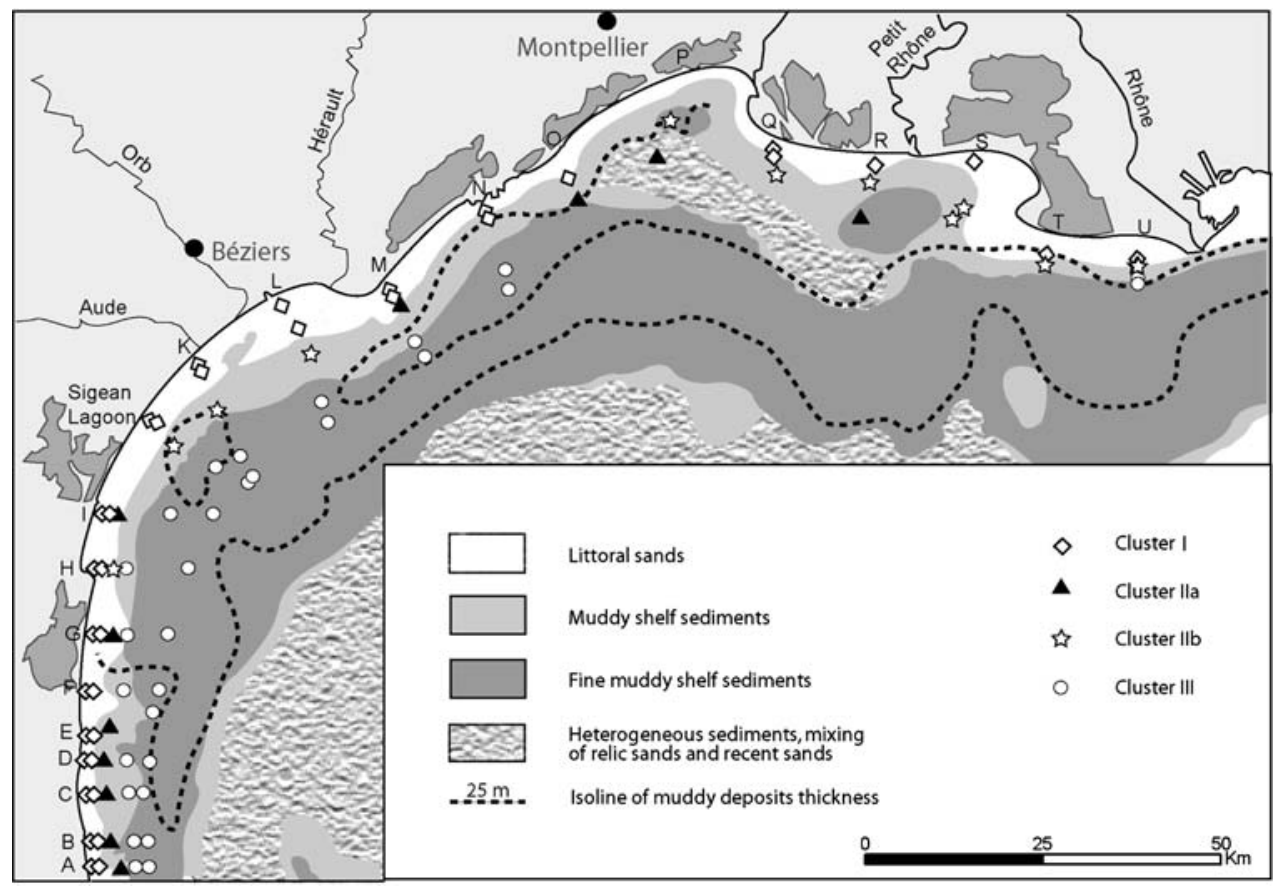

$30 \mathrm{~m}$ depth. Sediment samples were collected with a $0.1 \mathrm{~m}^{2}$ Van Veen grab. At each site, three grabs were taken for the analysis of benthic macrofauna. Macrofauna samples were immediately sieved on a $1 \mathrm{~mm}$ mesh and the retained fauna were fixed in 5\% formalin. Samples were sorted and macrofauna were later identified to the lowest practical taxonomic level and counted. The unidentified species were only taken into account when they could not be mistaken for other identified species. Macrofauna analyses were carried out on data pooled over the three replicated sampling units (Ellingsen 2001). Granulometric analysis was conducted on fresh sediment using a Malvern ${ }^{\circledR}$ Mastersizer 2000 laser microgranulometer. Organic carbon was measured after acidification $(\mathrm{HCl} 1 \mathrm{~N})$ of freeze-dried sediment using a CHN Perkin Elmer ${ }^{\circledR} 2400$ analyzer.

\section{Data analysis}

The frequency distributions of species range within major taxonomic groups were compared using KolmogorovSmirnov tests. Correlations between standardized similarity matrices of each major taxonomic group and of total macrofauna were tested for significance using Mantel tests. Macrofauna communities were determined through cluster analysis based on macrofauna composition (abundance square-root transformed data, Bray-Curtis similarity, average link grouping). This technique is appropriate for delineating groups of sites with distinct community structure and has proved useful in a number of ecological studies over the last three decades (Clarke and Warwick
2001). This analysis was carried out using the PRIMER ${ }^{\circledR}$ computer software. The average proportion of silt-clay particles $(<63 \mu \mathrm{m})$ and organic carbon contents of the clusters were compared using Kruskal-Wallis ANOVAs. The average contributions of each major taxonomic group to species richness of the total macrofauna within each cluster were qualitatively compared. The species most responsible for similarity within clusters and dissimilarities between clusters were assessed using the SIMPER procedure of the PRIMER ${ }^{\circledR}$ package. The significance of the correlations between macrofauna composition and abiotic parameters (i.e., depth, percentage of silt-clay and organic carbon contents) were assessed by Mantel tests.

We used the same $\alpha$-diversity indices as Labrune et al. (2006b), namely: species richness $(S)$, Shannon-Wiener index $\left(H^{\prime}\left(\log _{2}\right)\right)$, Pielou's evenness $\left(J^{\prime}\right)$, and average taxonomic distinctness $\left(\Delta^{*}\right)$. These four indices were computed using the PRIMER ${ }^{\circledR}$ package. The average values of these indices within each cluster were compared using KruskalWallis ANOVAs. The relationships between species richness of total macrofauna and of major taxonomic groups were assessed using stepwise (forward) multiple linear regression models, both for individual clusters and for the whole data set. Simple linear regression models were used for the three other $\alpha$-diversity indices.

$\beta$-diversity was computed as the ratio between the regional $(\gamma)$ and the average local $\bar{\alpha}$-diversity (Whittaker 1972). Cumulative curves of $\beta_{w}$ were computed based on randomly generated subsets of sampling sites (Ellingsen 2001, 2002). These computations were carried out for: (1) total macrofauna and each major taxonomic group, and (2) 
for the whole data set and each cluster separately. Cumulative $\beta_{w}$ curves were generated using specially programmed Matlab ${ }^{\circledR}$ routines.

We used the same estimators as Labrune et al. (2006b) to assess the true numbers of species within each cluster: $S_{\text {obs }}$, $\mathrm{Chao}_{1}, \mathrm{Chao}_{2}$ and ICE. $S_{\text {obs }}$ is the total number of species recorded in the whole data set. Cumulative curves of these indices were established by randomly generating subsets of sampling sites increasing in size. This procedure (50 randomizations) was carried out using the EstimateS freeware (Colwell 1997). Both Chao's and ICE estimators were used on homogeneous subsets of samples as recommended by Foggo et al. (2003a, 2003b) and Magurran (2004). We used two extrapolation methods to infer $\gamma$-diversity (i.e., the total number of species in the whole studied area): (1) the extrapolation of the species accumulation curve, and (2) the "total species-accumulation curve" (TS). This latter method has been recently introduced by Ugland et al. (2003). It consists in constructing a regression of the average number of species in all combinations of, respectively, one, two, three and four predefined subsets of sites versus the logarithm of the cumulative number of samples in each of these combinations. This regression is then extrapolated to the whole surface of the studied area. According to Ugland et al. (2003, 2005), the TS method provides more realistic estimates of total species richness than the usual estimators, which result in important underestimations. Labrune et al. (2006b) recently argued that the TS method provides more accurate results when subsets of sites do not correspond to macrofauna communities/assemblages. The rationale for that is that the whole studied area does not necessarily contain more communities than the ones already identified. During the present study, we therefore used the TS method based on four geographical sub-areas (area $1=$ transect $\mathrm{A}$ to $\mathrm{E}$, area $2=$ transect $\mathrm{F}$ to $\mathrm{J}$, area $3=$ transect $\mathrm{K}$ to $\mathrm{P}$, area $4=$ transect $\mathrm{Q}$ to $\mathrm{U}$ ). For both estimation methods, the total surface area of the studied area was estimated as $2921 \mathrm{~km}^{2}$ and the surface area represented by one sampling unit was considered to be $0.3 \mathrm{~m}^{2}$ (i.e., the true sampled surface area at each site).

\section{Results}

A total of 26,999 individuals belonging to 425 species were identified during the present study, including 173 species of polychaetes, 133 species of crustaceans, 86 species of molluscs and 15 species of echinoderms. Of the ten most abundant species, six were polychaetes, three were molluscs and one was a crustacean. The most dominant species was the serpulid Ditrupa arietina, which accounted for $27.3 \%$ of total macrofauna abundance. The oweniid Owenia fusiformis accounted for $9.8 \%$ and the turritellid
Turitella communis for $6.4 \%$ of the total macrofauna abundance. The two most widespread species were Lumbrineris latreilli and Tanaidacae ind., which were present at 79 and 80 sites, respectively. The ranges of the other most abundant species were much more restricted (i.e., 43, 40 and 42 sites for D. arietina, O. fusiformis and T. communis, respectively) and 119 species were singletons. Species range distribution curves for each major taxonomic group are shown in Fig. 2. Although polychaetes, crustaceans and molluscs featured a quite similar general pattern (i.e., right skewed distributions), the frequency distributions of species range significantly differed among major taxonomic groups (Kolmogorov-Smirnov tests, $P<0.01$, except for crustaceans and molluscs for which $P>0.05)$. This pattern was less clear for echinoderms due to a lower number of species. Polychaetes and crustaceans had both 40 species present at only one site, while molluscs and echinoderms had 29 and 4, respectively. Polychaetes had 25 species present at more than 20 sites versus 13 for molluscs, 12 for crustaceans and 6 species for echinoderms, respectively.
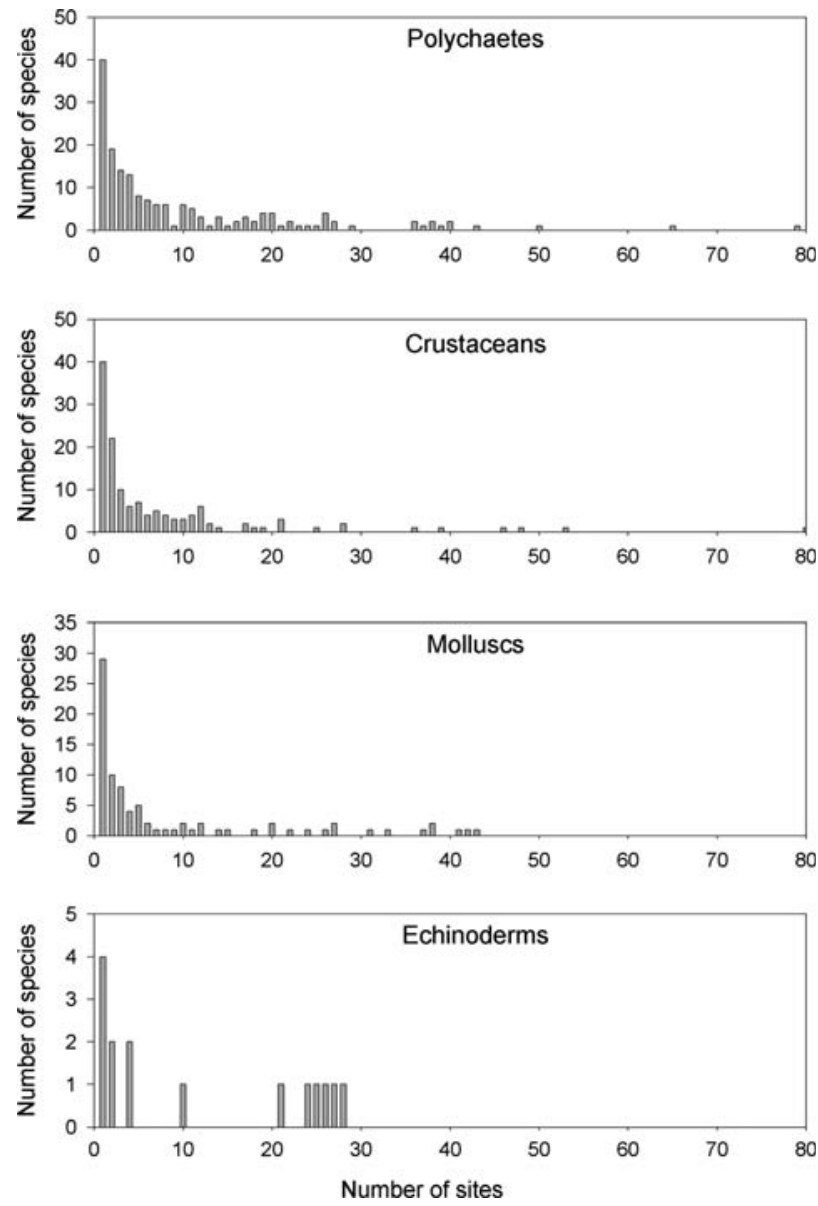

Fig. 2 Distributions of species ranges for the four major taxonomic groups 


\section{Cluster definition and composition}

Total macrofauna composition correlated most tightly with the composition of polychaetes (Mantel test, $\rho=0.927$, $P<0.001)$, followed by molluscs, echinoderms and crustaceans (Mantel tests, $\rho=0.700,0.682$ and 0.596, respectively, with $P<0.001$ in all cases). The results of the cluster analysis based on total macrofauna composition are presented in Fig. 3.

Three main clusters were identified based on a $25 \%$ similarity level. The first cluster mainly grouped sites in 10 and $20 \mathrm{~m}$ depth (except T10 and U10, which both featured extremely low species richness). The second cluster mainly grouped sites $30 \mathrm{~m}$ depth and could be divided into two sub-clusters as already proposed by Labrune et al. (2007) for polychaetes. The third cluster grouped all sites in 40 and $50 \mathrm{~m}$ depth except E40, which was more similar to the sites of cluster II. The locations of sites belonging to the four clusters and sub-clusters, identified based on macrofauna composition, are shown in Fig. 1.

The average cumulated granulometric curves and organic carbon contents within each cluster are shown in Fig. 4. There were marked differences in sediment granulometry among clusters with a gradient from coarser to finer sediments between clusters I and III and a clear difference between clusters IIa and IIb as well. The mean proportions of silt-clay significantly differed among clusters (KruskalWallis ANOVA, $P<0.001)$. Sediments mostly consisted of fine sands in cluster I, muddy sands in cluster IIa, sandy mud in cluster IIb and fine mud in cluster III. Mean organic carbon contents significantly differed among clusters (Kruskal-Wallis ANOVA, $P<0.001$ ) and correlated positively with silt-clay contents $(r=0.94, \quad P<0.001)$. Organic carbon contents were lower in clusters I and IIa and higher in clusters IIb and III. There were significant correlations between macrofauna composition and depth (Mantel
Fig. 3 Cluster analysis based on benthic macrofauna abundance

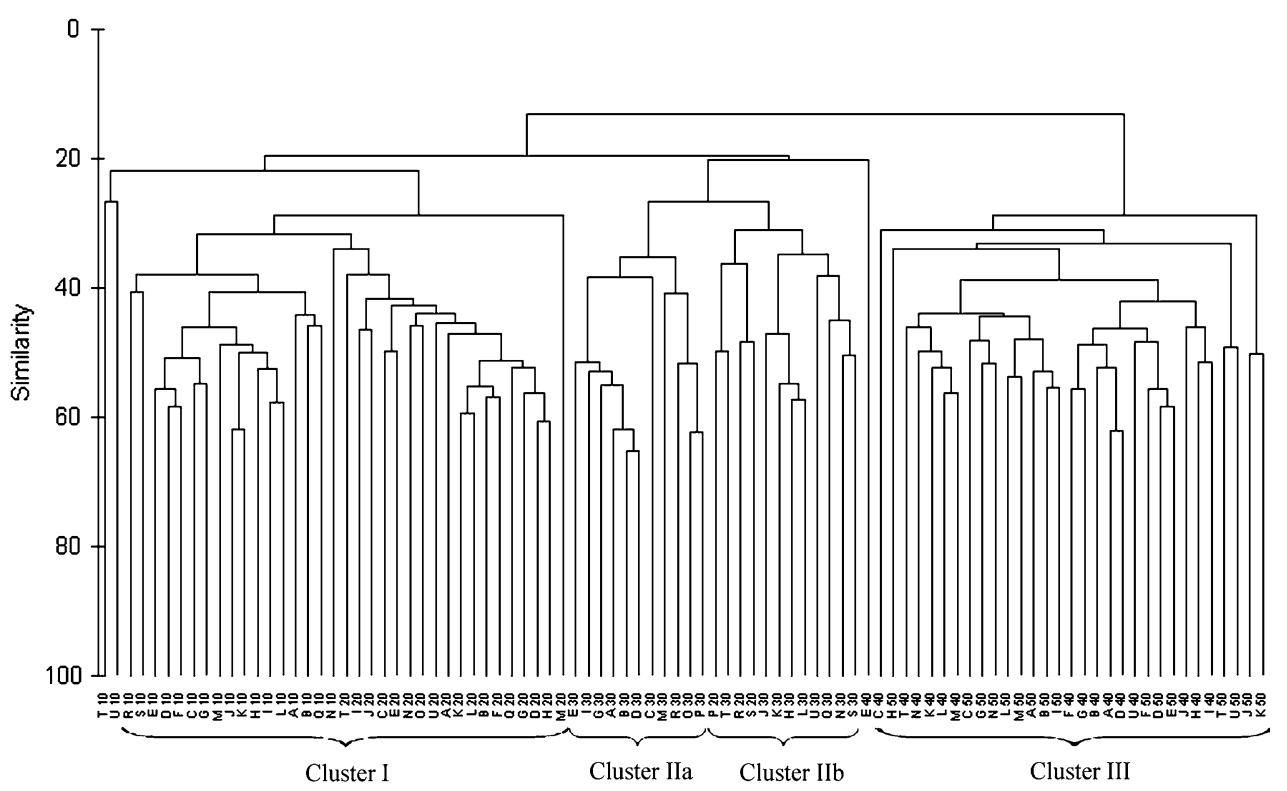

Fig. 4 Average cumulated granulometric curves (a), and organic carbon contents (b) of surface sediments in the four main clusters and sub-clusters identified on the basis of total macrofauna composition. Vertical bars are standard deviations
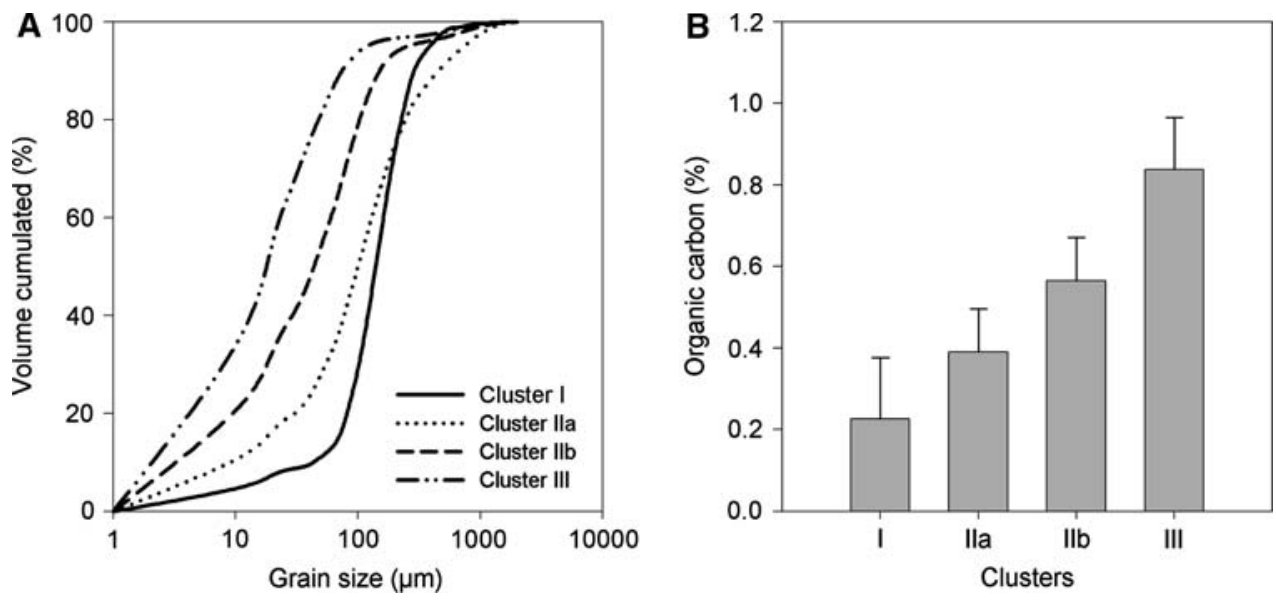


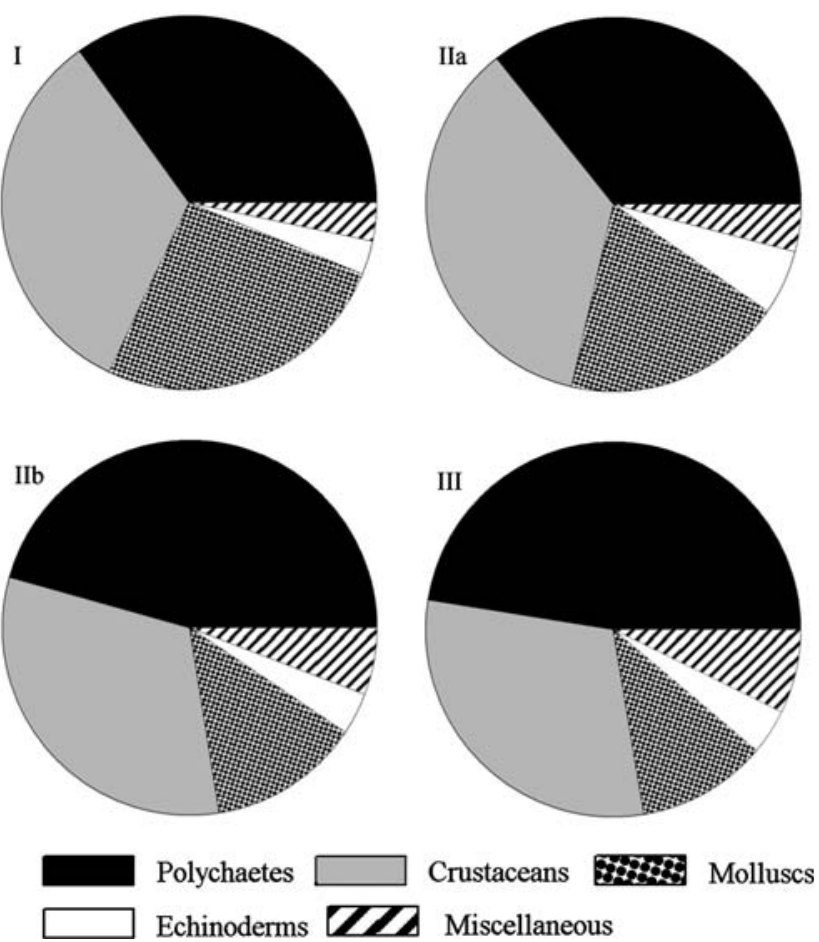

Fig. 5 Contributions of the four major taxonomic groups to the species richness of the total macrofauna within the four main clusters and sub-clusters identified on the basis of total macrofauna composition

test, $\rho=0.788, P<0.001$ ), percentage of silt-clay (Mantel test, $\rho=0.735, P<0.001$ ), and organic carbon content (Mantel tests, $\rho=0.706, P<0.001$ ).

Polychaetes and crustaceans were the two major taxonomic groups contributing most to total macrofauna species richness (Fig. 5). The relative contributions of each major taxonomic group to total species richness within each cluster are shown in Fig. 5. The contribution of polychaetes tended to increase from cluster I to cluster III. Crustaceans and molluscs showed an opposite trend. The contribution of echinoderms was maximal in cluster IIa.

Contributions and cumulative contributions of the ten species most responsible for similarities within each cluster are shown in Table 1. Polychaetes accounted for seven, five, four and six of these ten species in clusters I, IIa, IIb and III, respectively. Species most responsible for dissimilarities between clusters are listed in Table 2 .

Different components of macrofauna diversity

Average values and standard deviations of the four indices of $\alpha$-diversity of total macrofauna within each cluster are shown in Fig. 6. All indices featured significant differences among clusters (Kruskal-Wallis ANOVAs, $P<0.001$ in all cases). Mean species richness was higher in clusters I
Table 1 Contributions and cumulative contributions of the species most responsible for similarity within each cluster identified on the basis of total macrofauna composition

\begin{tabular}{|c|c|c|c|}
\hline & Species & $\begin{array}{l}\text { Contribution } \\
(\%)\end{array}$ & $\begin{array}{l}\text { Cumulative } \\
\text { contribution } \\
\text { (\%) }\end{array}$ \\
\hline \multirow[t]{10}{*}{ Cluster I } & Ditrupa arietina & 12.90 & 12.90 \\
\hline & Owenia fusiformis & 10.48 & 23.38 \\
\hline & Tanaidacae ind. & 5.89 & 29.26 \\
\hline & Spisula subtruncata & 5.33 & 34.59 \\
\hline & Chone duneri & 5.09 & 39.68 \\
\hline & Nephtys hombergii & 4.35 & 44.03 \\
\hline & Glycera unicornis & 4.28 & 48.31 \\
\hline & Aponuphis bilineata & 3.98 & 52.29 \\
\hline & Corbula gibba & 2.58 & 54.88 \\
\hline & Lumbrineris latreilli & 2.48 & 57.36 \\
\hline \multirow[t]{10}{*}{ Cluster IIa } & Ditrupa arietina & 10.31 & 10.31 \\
\hline & Lumbrineris latreilli & 7.44 & 17.75 \\
\hline & Tanaidacae ind. & 6.45 & 24.20 \\
\hline & Goniada spp. & 4.76 & 28.97 \\
\hline & Aponuphis bilineata. & 4.75 & 33.71 \\
\hline & Tellina pulchella & 3.79 & 37.51 \\
\hline & Scoletoma impatiens & 3.56 & 41.06 \\
\hline & Nucula nitidosa & 3.45 & 44.51 \\
\hline & Phaxas pellucidus & 3.29 & 47.80 \\
\hline & Amphiura chiajei & 2.57 & 50.37 \\
\hline \multirow[t]{10}{*}{ Cluster IIb } & Lumbrineris latreilli & 20.21 & 20.21 \\
\hline & Turitella communis. & 20.11 & 40.32 \\
\hline & Tanaidacae ind. & 6.62 & 46.94 \\
\hline & Notomastus sp. & 6.01 & 52.95 \\
\hline & Amphiura chiajei & 4.09 & 57.04 \\
\hline & Ampelica typica & 4.07 & 61.11 \\
\hline & Scoletoma impatiens & 2.52 & 63.63 \\
\hline & Nucula nitidosa & 2.51 & 66.15 \\
\hline & Ampelisca diadema & 2.43 & 68.58 \\
\hline & Aspidosiphon mиelleri & 2.05 & 70.63 \\
\hline \multirow[t]{10}{*}{ Cluster III } & Sternaspis scutata & 12.70 & 12.70 \\
\hline & Lumbrineris latreilli & 11.09 & 23.79 \\
\hline & Nephtys incisa & 7.78 & 31.57 \\
\hline & Tanaidacae ind. & 6.84 & 38.40 \\
\hline & Heteromastus filiformis & 4.45 & 42.86 \\
\hline & $\begin{array}{l}\text { Scoletoma emandibula } \\
\quad \text { mabiti }\end{array}$ & 4.02 & 46.87 \\
\hline & Labidoplax digitata & 3.95 & 50.83 \\
\hline & Glycera unicornis & 3.61 & 54.43 \\
\hline & Ampelisca diadema & 3.33 & 57.76 \\
\hline & Goneplax rhomboides & 3.00 & 60.76 \\
\hline
\end{tabular}

and IIa than in clusters IIb and III. Changes in average $\mathrm{H}^{\prime}$ were more limited with higher values in clusters IIa and III and lower ones in clusters I and IIb. Average $J^{\prime}$ were 
Table 2 Contributions and average abundances of species responsible for most of the dissimilarities between clusters identified based on total macrofauna composition
Fig. 6 Average species richness (a), Shannon index (b), Pielou evenness (c), and taxonomic distinctness (d) for the four main clusters and subclusters identified on the basis of total macrofauna composition. Vertical lines are standard deviations

\begin{tabular}{|c|c|c|c|c|c|}
\hline $\begin{array}{l}\text { First } \\
\text { cluster }\end{array}$ & $\begin{array}{l}\text { Second } \\
\text { cluster }\end{array}$ & Species & $\begin{array}{l}\text { Average abundance, } \\
\text { first cluster }\end{array}$ & $\begin{array}{l}\text { Average abundance, } \\
\text { second cluster }\end{array}$ & $\begin{array}{l}\text { Cumulative } \\
\text { contribution (\%) }\end{array}$ \\
\hline \multirow[t]{6}{*}{ I } & \multirow[t]{6}{*}{ IIa } & Ditrupa arietina & 497.19 & 638.18 & 5.66 \\
\hline & & Owenia fusiformis & 253.20 & 1.82 & 9.68 \\
\hline & & Lumbrineris latreilli & 17.29 & 119.09 & 12.12 \\
\hline & & Tanaidacae ind. & 49.90 & 118.18 & 14.39 \\
\hline & & Spisula subtruncata & 82.24 & 0.61 & 16.60 \\
\hline & & Goniada sp. & 0.00 & 36.67 & 18.56 \\
\hline \multirow[t]{5}{*}{ IIa } & \multirow[t]{5}{*}{ IIb } & Ditrupa arietina & 638.18 & 1.67 & 7.59 \\
\hline & & Turritella communis & 6.36 & 434.73 & 13.08 \\
\hline & & Tanaidacae ind. & 118.18 & 33.06 & 15.87 \\
\hline & & Aponuphis bilineata & 36.97 & 0.28 & 18.16 \\
\hline & & Lumbrineris latreilli & 119.09 & 126.94 & 20.20 \\
\hline \multirow[t]{6}{*}{ IIb } & \multirow[t]{6}{*}{ III } & Turitella communis & 434.73 & 7.74 & 8.91 \\
\hline & & Lumbrineris latreilli & 126.94 & 40.86 & 12.95 \\
\hline & & Amphiura chiajei & 25.83 & 1.61 & 15.36 \\
\hline & & Sthenelais boa & 4.72 & 24.62 & 17.63 \\
\hline & & Ampelisca typica & 22.78 & 2.26 & 19.82 \\
\hline & & Ampelisca diadema & 31.11 & 7.74 & 22.01 \\
\hline
\end{tabular}
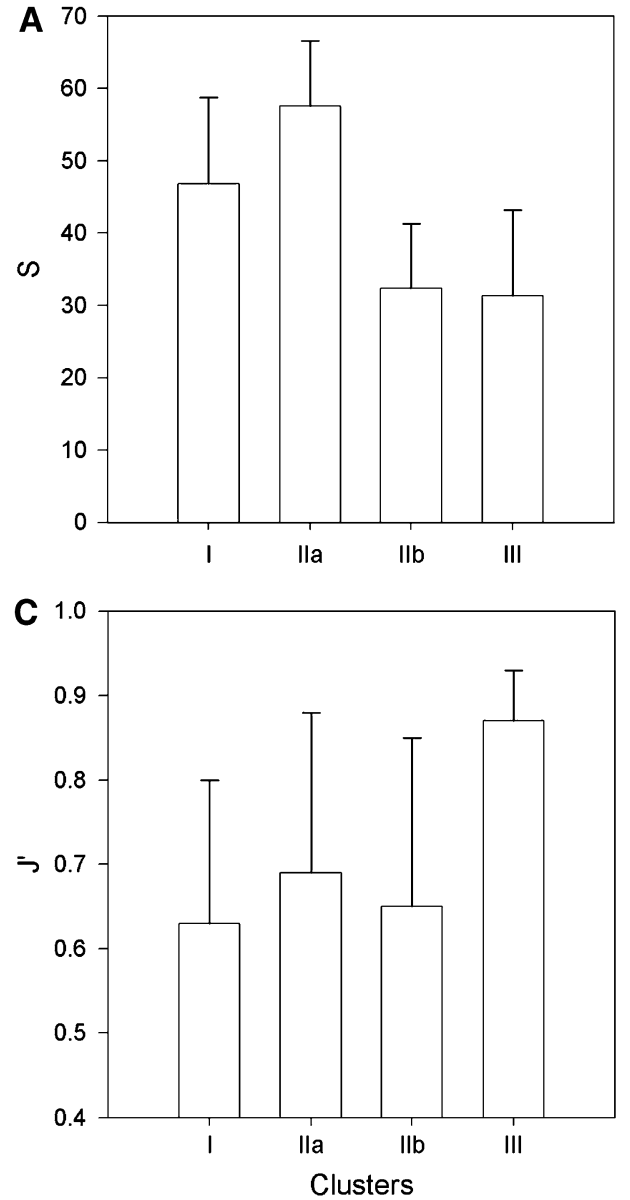
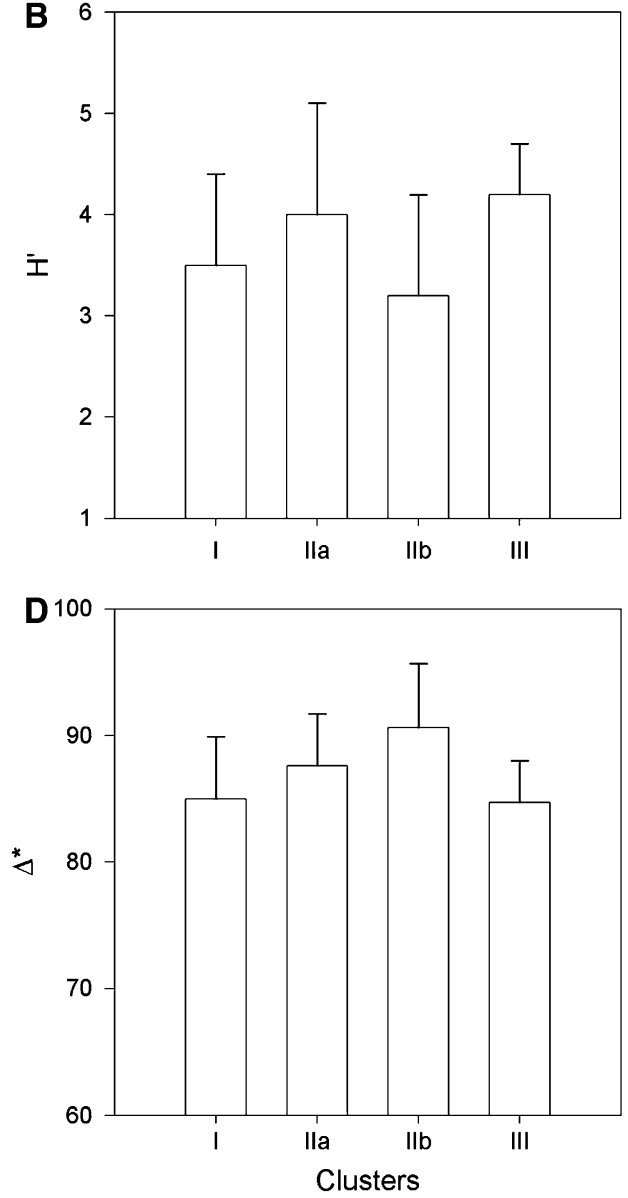
almost similar in clusters I, IIa and IIb, and much higher in cluster III. Average $\Delta^{*}$ showed only limited changes among clusters with increasing values between clusters I and IIb and then decreasing ones between clusters IIb and III.

The main characteristics of the stepwise multiple regression models linking the species richness of major taxonomic groups and the species richness of total macrofauna are shown in Table 3 . The combination of major taxa best accounting for the species richness of total macrofauna clearly differed between clusters. Overall species richness of crustaceans and polychaetes correlated best with species richness of total macrofauna. Molluscs were also always included in the best combination of major taxa, which conversely was not the case for echinoderms.

Relationships between the other $\alpha$-diversity indices of each major taxonomic groups and total macrofauna are shown in Table $4 . \mathrm{H}^{\prime}$ and $\mathrm{J}^{\prime}$ of polychaetes correlated best

Table 3 Adjusted $r^{2}$ of the forward stepwise multiple regression models linking species richness of total macrofauna and of major taxonomic groups

\begin{tabular}{|c|c|c|}
\hline & $\begin{array}{l}\text { Variables and } \\
\text { coefficients }\end{array}$ & $\begin{array}{l}\text { Adjusted } \\
\text { cumulated } r^{2}\end{array}$ \\
\hline \multirow[t]{5}{*}{ Cluster I $(N=35)$} & Cte $=-1.106$ & \\
\hline & $\mathrm{Pol}=1.084$ & 0.581 \\
\hline & Cru $=1.052$ & 0.830 \\
\hline & $\mathrm{Mol}=0.938$ & 0.986 \\
\hline & $\mathrm{Ech}=1.266$ & 0.996 \\
\hline \multirow[t]{4}{*}{ Cluster IIa $(N=11)$} & Cte $=7.037$ & 0.614 \\
\hline & $\mathrm{Cru}=0.855$ & 0.773 \\
\hline & $\mathrm{Mol}=1.127$ & 0.994 \\
\hline & $\mathrm{Pol}=0.983$ & \\
\hline \multirow[t]{4}{*}{ Cluster IIb $(N=12)$} & Cte $=-0.553$ & \\
\hline & $\mathrm{Cru}=1.320$ & 0.517 \\
\hline & Pol $=1.200$ & 0.948 \\
\hline & $\mathrm{Mol}=0.741$ & 0.981 \\
\hline \multirow[t]{5}{*}{ Cluster III $(N=3)$} & $\mathrm{Cte}=0.551$ & \\
\hline & Pol $=1.076$ & 0.885 \\
\hline & $\mathrm{Cru}=0.929$ & 0.971 \\
\hline & $\mathrm{Mol}=1.049$ & 0.985 \\
\hline & $\mathrm{Ech}=1.068$ & 0.990 \\
\hline \multirow[t]{5}{*}{ Whole area $(N=92)$} & $\mathrm{Cte}=0.453$ & \\
\hline & $\mathrm{Cru}=1.009$ & 0.623 \\
\hline & $\mathrm{Pol}=1.453$ & 0.889 \\
\hline & $\mathrm{Mol}=0.936$ & 0.986 \\
\hline & $\mathrm{Ech}=1.120$ & 0.994 \\
\hline
\end{tabular}

Coefficients are provided both for individual clusters and for the whole data set. Probability threshold: 0.005

Cte contant, $\mathrm{Pol}$ polychaetes, $\mathrm{Cr}$ crustaceans, $\mathrm{Mol}$ molluscs, Ech echinoderms with those of the total macrofauna within the whole studied area and within all clusters but IIb (where molluscs correlated better). Only the $\Delta^{*}$ of polychaetes in cluster I, of molluscs in the whole studied area and of echinoderms in cluster III correlated significantly with those of the total macrofauna. Determination coefficients were always less than 0.36 , which was much lower than those recorded for the three other indices of $\alpha$-diversity.

Figure 7 shows the $\beta_{w}$ accumulation curves based on samples from the whole studied area. Corresponding $\beta_{w}$ were: 10.4 for total macrofauna; $12.3,10.7,9.1$ and 7.8 for crustaceans, molluscs, polychaetes and echinoderms, respectively. The pattern of $\beta_{w}$ differed among clusters (Fig. 8). In cluster I, total macrofauna and molluscs featured the highest $\beta_{w}$, whereas the other major taxonomic groups all featured lower and quite similar $\beta_{w}$. In cluster IIa, total macrofauna featured the highest $\beta_{w}$ and all major taxonomic groups featured lower and quite similar $\beta_{w}$. In cluster IIb, polychaetes featured the highest $\beta_{w}$ followed by total macrofauna, whereas the three other dominant taxonomic groups featured much lower $\beta_{w}$. In cluster III, molluscs featured by far the highest $\beta_{w}$, followed by total macrofauna, polychaetes, crustaceans and echinoderms, which featured very similar $\beta_{w}$.

Cumulative curves of the estimators of total species richness within each cluster are shown in Fig. 9. $\mathrm{ChaO}_{2}$ and ICE always led to the highest estimates followed by $\mathrm{Chao}_{1}$ and $S_{\text {obs. }}$. None of the tested estimators reached an asymptote in any of the four clusters. Since the estimates of total species richness depend on sampling effort, they were compared between clusters for a standardized sampling effort (i.e., 11 sampling sites, which correspond to the number of sites in the smallest cluster). On this ground, cluster IIa featured the highest total species richness followed by clusters I, IIb and III.

The two estimates of total species number within the whole studied area are presented in Fig. 10. The extrapolation of the species accumulation resulted in an estimation of 2,082 species versus 2,319 species when using the TS method.

\section{Discussion}

Main soft-bottom macrofauna communities

The first quantitative descriptions of Mediterranean softbottom macrofauna have been carried out independently along the Provence and the French Catalan coasts, which has resulted in two distinct denominations for most communities (Picard 1965; Guille 1971). Since most communities have then been found elsewhere in the Mediterranean (Desbruyères et al. 1972; Gamulin-Brida 
Table 4 Determination coefficients $\left(r^{2}\right)$ of the simple linear regression models linking $\alpha$-diversity indices for total macrofauna and for each major taxonomic group
Coefficients are provided both for individual clusters and for the whole data set. Significant positive correlations $(P<0.05)$ are in bold

\begin{tabular}{llllll}
\hline$H^{\prime}$ & $\begin{array}{l}\text { Cluster I } \\
(N=35)\end{array}$ & $\begin{array}{l}\text { Cluster IIa } \\
(N=11)\end{array}$ & $\begin{array}{l}\text { Cluster IIb } \\
(N=12)\end{array}$ & $\begin{array}{l}\text { Cluster III } \\
(N=31)\end{array}$ & $\begin{array}{l}\text { Whole area } \\
(N=92)\end{array}$ \\
\hline Polychaetes & $\mathbf{0 . 8 3}$ & $\mathbf{0 . 8 4}$ & 0.04 & $\mathbf{0 . 7 2}$ & $\mathbf{0 . 6 7}$ \\
Crustaceans & 0.07 & 0.02 & 0.03 & $\mathbf{0 . 4 2}$ & 0.04 \\
Molluscs & 0.00 & 0.01 & $\mathbf{0 . 4 2}$ & $\mathbf{0 . 2 6}$ & 0.00 \\
Echinoderms & 0.09 & $\mathbf{0 . 4 5}$ & 0.10 & $\mathbf{0 . 2 3}$ & 0.03 \\
\hline$J^{\prime}$ & Cluster I & Cluster IIa & Cluster IIb & Cluster III & Whole area \\
& $(N=35)$ & $(N=11)$ & $(N=12)$ & $(N=31)$ & $(N=92)$ \\
\hline Polychaetes & $\mathbf{0 . 0 0}$ & $\mathbf{0 . 8 9}$ & 0.00 & $\mathbf{0 . 6 9}$ & $\mathbf{0 . 6 9}$ \\
Crustaceans & 0.01 & 0.38 & 0.01 & 0.01 & 0.04 \\
Molluscs & 0.01 & 0.25 & $\mathbf{0 . 5 4}$ & 0.01 & $\mathbf{0 . 0 5}$ \\
Echinoderms & 0.00 & $\mathbf{0 . 4 4}$ & 0.29 & 0.18 & $\mathbf{0 . 0 8}$ \\
\hline$\Delta^{*}$ & Cluster I & Cluster IIa & Cluster IIb & Cluster III & Whole area \\
& $(N=35)$ & $(N=11)$ & $(N=12)$ & $(N=31)$ & $(N=92)$ \\
\hline Polychaetes & $\mathbf{0 . 3 6}$ & 0.06 & 0.04 & 0.01 & 0.02 \\
Crustaceans & 0.05 & 0.01 & 0.28 & 0.01 & 0.00 \\
Molluscs & 0.07 & 0.01 & 0.00 & 0.03 & $\mathbf{0 . 0 5}$ \\
Echinoderms & 0.03 & 0.02 & 0.01 & $\mathbf{0 . 3 4}$ & 0.00 \\
\hline
\end{tabular}

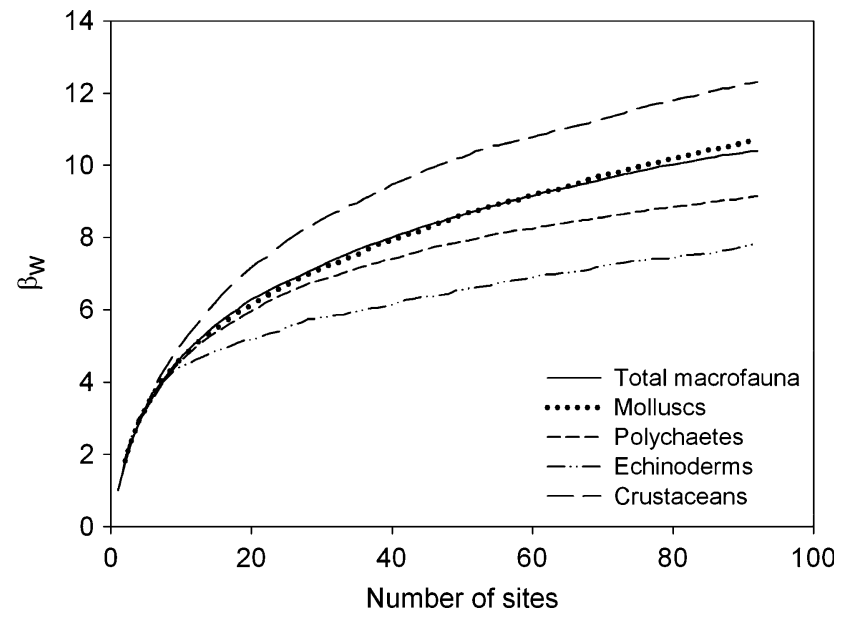

Fig. 7 Cumulated curves of $\beta_{w}$ based on 50 randomizations for the four major taxonomic groups and total macrofauna in the whole studied area

1974; Dounas and Koukouras 1992; Karakassis and Eleftheriou 1997; Tselepides et al. 2000) or even in other areas in the world (Probert and Grove 1998), this requires some clarification. During the present study, we identified four main clusters and sub-clusters, which were very similar to those reported based on the sole analysis of polychaete fauna (Labrune et al. 2007). Cluster I tightly corresponded to the littoral fine sands assemblage (LFS), clusters IIa and IIb to the littoral sandy mud assemblages (LSM, with a distinction between southern and northern part), and cluster III to the terrigeneous coastal mud assemblage (TCM). We therefore propose that the terminology LSF/LSM/TCM should now be used to account for the three main communities of macrofauna in the littoral soft-bottoms of the Gulf of Lions.

\section{Components of macrofaunal diversity}

During the present study, species richness per site was between 10 and $76, H^{\prime}$ between 0.74 and 5.14, and $J^{\prime}$ between 0.16 and 0.94 . Great caution should be taken when comparing results of different studies due to possible heterogeneity in sampling strategies, gears and processing. Nevertheless, our results are coherent with those of $\mathrm{Al}$ bertelli et al. (1999) who assessed $\alpha$-diversity along a 5$135 \mathrm{~m}$ depth transect in the Ligurian Sea. At depths comparable to ours (i.e., 20 and $35 \mathrm{~m}$ ), species richness ranged between 54 and $89, H^{\prime}$ between 3.1 and 3.2, and $J^{\prime}$ between 0.7 and 0.8

The overall $\beta_{w}$ value recorded in the present study was 10.4. To our knowledge, $\beta_{w}$ values in the Mediterranean Sea are still lacking. However, our value can be compared with values reported for the North Sea ( 2.6 by Ellingsen 2001; 5.0 by Ellingsen 2002; 9.3 by Ellingsen and Gray 2002) and the Hong Kong waters (11.0 by Shin and Ellingsen 2004). Our $\beta_{w}$ value is thus indicative of high $\beta$-diversity (Shin and Ellingsen 2004). The heterogeneity in the $\beta_{w}$ values in the North Sea largely results from the diversity of sampled habitats (Ellingsen 2002). When computed for the different clusters, our $\beta_{\mathrm{w}}$ values were 
Fig. 8 Cumulated curves of $\beta_{w}$ based on 50 randomizations for the four major taxonomic groups and total macrofauna for cluster I (a), cluster IIa (b), cluster IIb (c) and cluster III (d). Dashed lines correspond to a standardized sampling effort of 11 sites
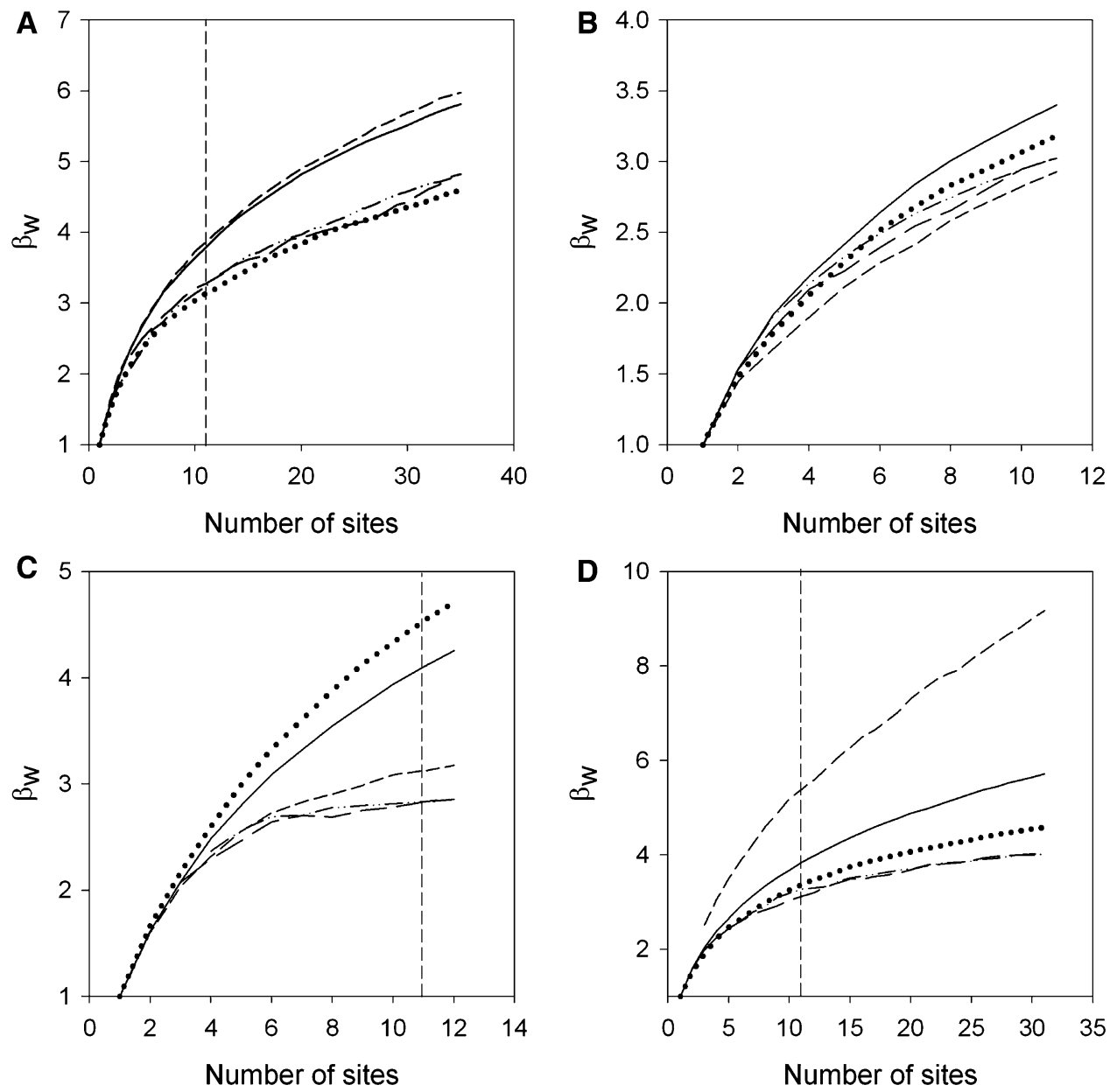

Total macrofauna ...... Polychaetes --- Molluscs $-\cdot-$ Crustaceans - - Echinoderms

between 3.4 (cluster IIa) and 5.8 (cluster I), which was still higher than the value reported for a single North Sea habitat by Ellingsen (2001). Thus, irrespective of the heterogeneity of sampled habitats, our results suggest that $\beta$-diversity of soft-bottom macrofauna is higher in the Gulf of Lions than in the North Sea.

All three indices provided reasonably close estimates, although slightly higher for ICE and $\mathrm{ChaO}_{2}$ than for $\mathrm{ChaO}_{1}$. This result is in accordance with those of Foggo et al. (2003a), Magurran (2004) and Mackie et al. (2005). When standardized for sampling effort, these estimates were higher for cluster IIa than for clusters I, IIb and III, which differed from what was reported by Labrune et al. (2006b) based on the analysis of polychaete fauna (i.e., lower estimate for clusters IIa than for clusters IIb, I and III). It should be underlined that this discrepancy did not result from differences in the delimitation of clusters, since cluster III was also affected although its composition was exactly the same in both studies.
Overall, 425 species were recorded in the present study. The extrapolation of the species accumulation curve to the whole sampled area resulted in an estimation of an overall number of 2,082 species versus 2,319 for the TS method (Ugland et al. 2003). The difference between the results derived from these two approaches was low (i.e., about $10 \%$ of the TS value) as compared to the Norwegian continental shelf (about $78 \%$ of the TS value, Ugland et al. 2003). This probably reflects the higher homogeneity of the areas sampled in the present study. There are very few estimates of the overall number of species for soft-bottom macrofauna and these estimates are rather uncertain. Based on the comparison of estimates from the TS method with literature data on total macrofauna, Ugland et al. (2003) concluded that the TS method might provide appropriate estimates of total species numbers. Our estimate for the Gulf of Lions (2,319 species) is close to the one for the Hong Kong waters (2,254 species), but much smaller than the one for the Norwegian shelf $(5,403$ species; Ugland 
Fig. 9 Estimates of the total number of species within each of the four main clusters and basis of total macrofauna composition. Estimators are $S_{\text {obs }}$, $\mathrm{Chao}_{1}, \mathrm{ChaO}_{2}$ and ICE. Plotted values are means $\pm \mathrm{SD}$ of 50 estimates based on 50 randomizations. For clarity reasons, standard deviations are sub-clusters identified on the not shown
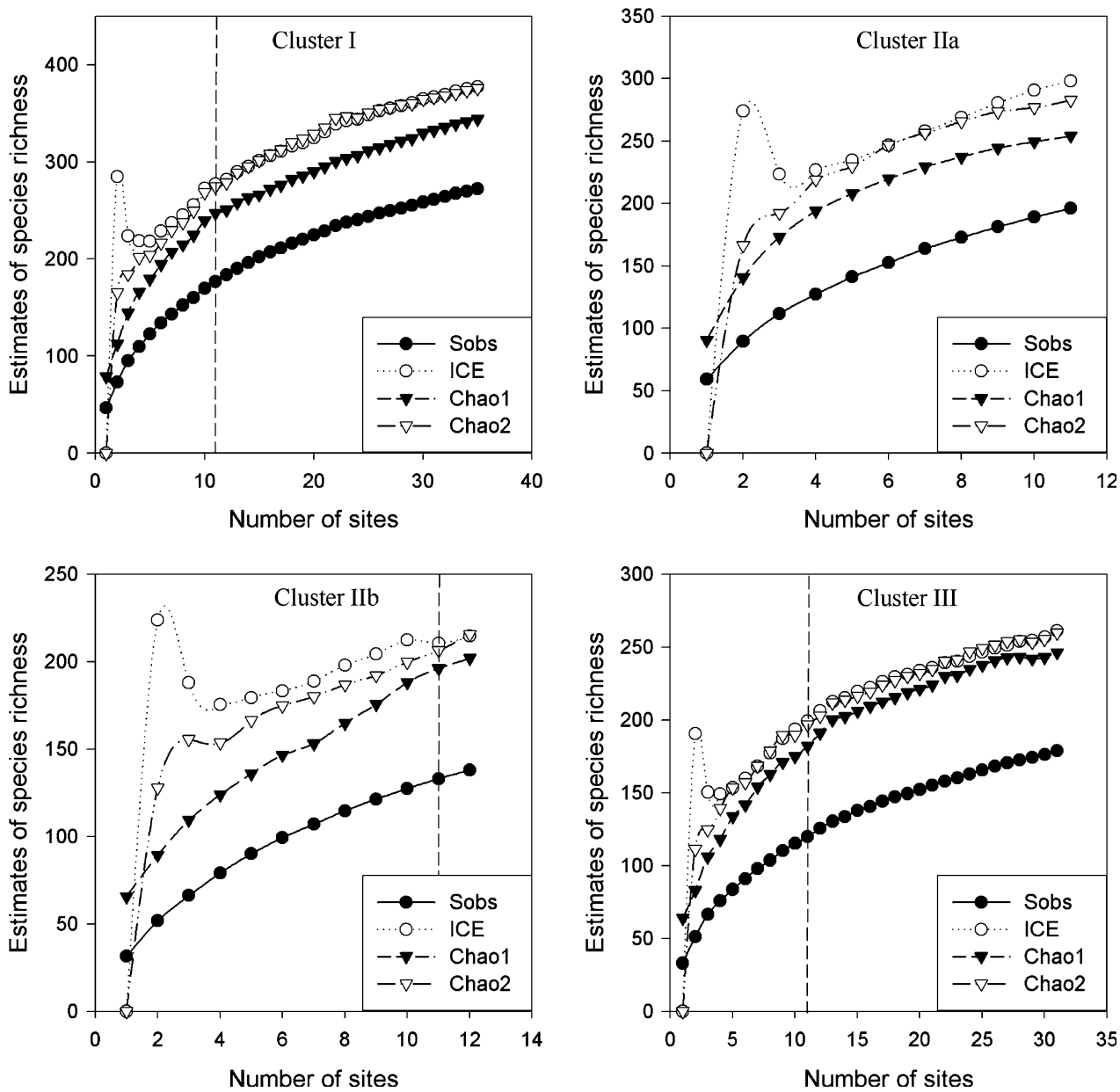

Fig. 10 Species accumulation curve for all combinations of one to four geographical subareas (a), and corresponding semi-logarithmic regression used for the estimation of true species richness (TS method; b). See text for details

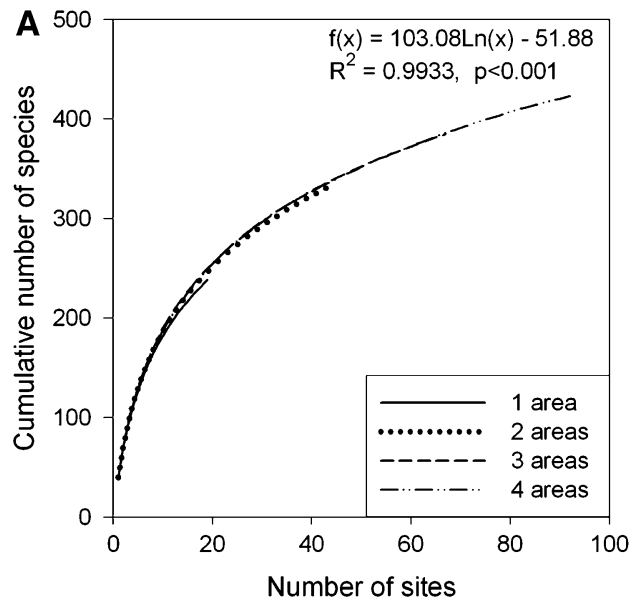

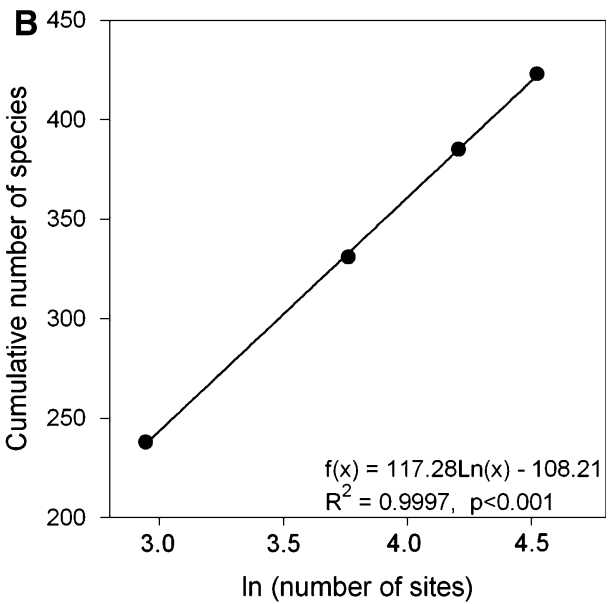

et al. 2003). The sampled depth range in the Gulf of Lions was almost similar to that in Hong Kong waters (Shin and Ellingsen 2004) and much lower than the one sampled on the Norwegian continental shelf (Ellingsen and Gray 2002). Thus, in agreement with Shin and Ellingsen (2004), differences in depth range may be responsible for the discrepancies in the total number of species.
Use of major taxonomic groups as surrogates for total macrofauna

For all major taxonomic groups the similarity matrix based on abundances correlated significantly with that for the total macrofauna. This correlation was highest for polychaetes, lowest for crustaceans and intermediate for 
molluscs and echinoderms. Similar results have already been reported for a set of North Sea sites (Olsgard and Somerfield 2000). The sequence reported by these authors was polychaetes $>$ molluscs $>$ crustaceans and no data were provided for echinoderms. The highest correlation found for polychaetes may have resulted partly from the fact that polychaetes represented the dominant group both in terms of abundance and species richness during the present study.

In spite of an overall good correlation between the compositions of total macrofauna and polychaete fauna, our results suggest that polychaetes do not always constitute a sound basis for classifying sites in areas of transition between sandy and muddy sediments. Out of the 92 sampled sites, 7 showed discrepancies in the classifications based on polychaete and total macrofauna composition. Most of these sites were located at the limit of areas characterized by different sediment granulometry (Labrune et al. 2007). K30 was located at the limit of the small area of muddy sediments off the Lagoon of Sigean and the River Aude, L30 was located off the mouth of the Hérault River; O30, P30 and R30 were located within and/or at the edge of the area of heterogeneous sediments off Montpellier (Aloisi et al. 1973). Discrepancies thus corresponded to the classification of sites in clusters characterized by a finer granulometry when using total macrofauna. The switch in the classification of H30, K30 and L30 from cluster IIa to IIb mainly resulted from high abundances of Turitella communis. The switch in the classification of O30, P30 and R30 resulted from the absence of Spisula subtruncata and high abundances of Tanaidacae ind. Spisula subtruncata is a suspension-feeder, which has long been known to be negatively affected by the increase of the proportion of fine particles within the sediment (Rhoads and Young 1970). On the contrary, most of the Tanaidacae and Turitella communis are known to prefer muddy substrates (Riedl 1983).

Overall species richness of crustaceans and polychaetes correlated best with species richness of total macrofauna. This is consistent with previous studies, which suggested that polychaetes as a whole (Olsgard and Somerfield 2000) or even a fraction of them (Olsgard et al. 2003) might be used as a surrogate for benthic macrofaunal species richness. Olsgard and Somerfield (2000) suggested that the correlation between indices computed for polychaetes and the total macrofauna were lower in pristine than in disturbed areas. Since the Gulf of Lions can be considered to be a non-perturbed area (Grémare et al. 1998; Rosenberg et al. 2003; Labrune et al. 2006a), our results support the use of polychaetes as a surrogate for the analysis of total macrobenthos species richness in soft-bottoms under moderate disturbance. They also highlight the fact that crustaceans are good surrogates as well for total macrobenthos species richness.
Olsgard and Somerfield (2000) also reported that $H^{\prime}$ of polychaetes correlated positively with those of total macrofauna. In the present study, polychaetes were the only major taxonomic group whose $H^{\prime}$ correlated positively with that of the total macrofauna when considering the whole sampled area. However, in the Gulf of Lions the significance of the relationship between $H^{\prime}$ and also $J^{\prime}$ values of polychaetes and the total macrofauna strongly differed between communities. Conversely, there was almost no significant correlation between the $\Delta^{*}$ of major taxa and total macrofauna. This is in agreement with Karakassis et al. (2006) who also reported a lack of constancy in the correlation of $\Delta^{*}$ obtained for all the studied components. In the present study, the scarcity of significant correlations recorded for $\Delta^{*}$ probably resulted from the fact that this index is largely independent of species richness and dominance (Clarke and Warwick 1998). Overall, our results suggest that the relevance of using polychaetes as surrogates for the $\alpha$-diversity of total macrofauna is highly dependent on the sampled cluster/communities. Therefore, this option should not be based on an a priori decision, but rather on the results of preliminary surveys (see Mackie et al. 2005, for the South Irish Sea) assessing at least the dominance patterns between and within major taxonomic groups.

There is also a crucial need to assess patterns of $\beta$ diversity among major taxonomic groups, which has only rarely been achieved in the marine environment. When considering the whole studied area, crustaceans featured the highest $\beta_{w}$, followed by molluscs, total macrofauna, polychaetes and echinoderms. This sequence is in good agreement with the few comparable data available for the marine environment. Crustaceans and molluscs both featured with high $\beta_{w}$ in the North Sea (Ellingsen 2001, 2002; Ellingsen and Gray 2002) and in Hong Kong waters (Shin and Ellingsen 2004). Conversely, polychaetes showed low $\beta_{w}$ values in all these studies, while data on echinoderms are scarcer (e.g., not provided in Shin and Ellingsen 2004) and more variable (e.g., Ellingsen 2001, 2002). High $\beta_{w}$ are usually attributed to the dominance of species with low distribution range (Harrison et al. 1992; Ellingsen 2001, 2002). Our results showed that there were significant differences in the distribution ranges of the major taxonomic groups and that polychaetes had a higher number of species with a wide distribution range than other major taxonomic groups, which partly accounted for their low $\beta_{w}$. There were also marked differences in the ranking of $\beta_{w}$ between the major taxonomic groups, depending on the considered cluster. Similar results have already been reported for distinct geographical areas both in the North Sea (Ellingsen and Gray 2002) and in Hong Kong waters (Shin and Ellingsen 2004). As for $\alpha$-diversity indices, this suggests that the validity of a major taxonomic group as a surrogate 
of total macrofauna is highly dependent on the considered environment. This confirms that a single taxonomic group cannot be taken to represent overall $\beta$-diversity (Ellingsen and Gray 2002).

Overall, our results show that the choice of a surrogate for total benthic macrofauna depends on the characteristic of the benthic macrofauna to be studied. Polychaetes clearly would constitute the best choice for an assessment of the overall composition of the soft-bottom macrofauna in the whole Gulf of Lions. In this particular case, polychaetes and crustaceans are also the best surrogates when assessing $\alpha$-diversity (except in the case of $\Delta^{*}$ ). Conversely, molluscs constituted the best surrogate of $\beta$ diversity. Moreover, the choice of an optimal surrogate also depends on the studied environment as shown by the important discrepancies between clusters reported in the present study.

Acknowledgments This work is part of the $\mathrm{PhD}$ thesis of Céline Labrune. It was carried out within the EC Network of Excellence MARBEF. Céline Labrune was supported by the SYSCOLAG project run by the Région Languedoc-Roussillon.

\section{References}

Albertelli G, Covazzi-Harriague A, Danovaro R, Fabiano M, Fraschetti S, Pusceddu A (1999) Differential responses of bacteria, meiofauna and macrofauna in a shelf area (Ligurian Sea, NW Mediterranean): role of food availability. J Sea Res 42:11-26

Aloisi JC, Got H, Monaco A (1973) Carte géologique du précontinent languedocien au 1/250000ième. Enschede : International Institute for Aerial Survey and Earth Sciences, Netherlands

Belan TA (2004) Marine environmental quality assessment using polychaete taxocene characteristics in Vancouver Harbour. Mar Environ Res 57:89-101

Bellan G, Bourcier M (1990) Les enseignements d'une étude sur dix ans (1976-1986) des peuplements de substrats meubles au large d'un émissaire d'eaux usées: Marseille-Cortiou. Cahier de Biologie Marine 31:225-249

Bellan G, Desrosiers G, Willsie A (1988) Use of an annelid pollution index for monitoring a moderately polluted littoral zone. Mar Pollut Bull 19:662-665

Bourcier M (1996) Long-term changes (1954 to 1982) in the benthic macrofauna under the combined effects of anthropogenic and climatic action (example of one Mediterranean Bay). Oceanologica Acta 19:67-78

Chao A (1984) Nonparametric estimation of the number of classes in a population. Scand J Stat 11:265-270

Clarke KR, Warwick RM (1998) A taxonomic distinctness index and its statistical properties. J Appl Ecol 25:523-531

Clarke KR, Warwick RM (2001) Change in marine communities: an approach to statistical analysis and interpretation, vol PRIMERE, Plymouth

Colwell RK (1997) EstimateS: statistical estimation of species richness and shared species from samples. Version 5. User's guide and application. Available at: http://viceroy.eeb.uconn. edu/estimates

Dauvin JC (1993) Le benthos: témoin des variations de l'environnement. Oceanis 19:25-53
Dauvin JC, Gomez Gesteira JL, Salvande Fraga M (2003) Taxonomic sufficiency: an overview of its use in the monitoring of sublittoral benthic communities after oil spills. Mar Pollut Bull 46:552-555

Desbruyères D, Guille A, Ramos JM (1972) Bionomie du plateau continental de la côte catalane espagnole. Vie et Milieu 23:335363

Dounas CG, Koukouras AS (1992) Circalittoral macrobenthic assemblages of Strymonikos Gulf (North Aegean Sea). P.S.Z.N.I: Mar Ecol 13:85-99

Ellingsen KE (2001) Biodiversity of a continental shelf soft-sediment macrobenthos community. Mar Ecol Prog Ser 218:1-15

Ellingsen KE (2002) Soft-sediment benthic biodiversity on the continental shelf to environmental variability. Mar Ecol Prog Ser 232:15-27

Ellingsen K, Gray JS (2002) Spatial patterns of benthic diversity: is there a latitudinal gradient along the Norwegian continental shelf? J Anim Ecol 71:373-389

Foggo A, Attrill MJ, Frost MT, Rowden AA (2003a) Estimating marine species richness: an evaluation of six extrapolative techniques. Mar Ecol Prog Ser 248:15-26

Foggo A, Rundle SD, Bilton DT (2003b) The net result: evaluating species richness extrapolation techniques for littoral pond invertebrates. Freshw Biol 48:1756-1764

Gamulin-Brida H (1974) Biocoenoses benthiques de la mer Adriatique. Acta Adriatica Institut za Oceanografiju i ribarstvo - split sfr jugoslavija 15:102

Gaston KJ, Spicer JI (1998) Biodiversity-an introduction. Blackwell Science, Oxford

Gesteira JLG, Dauvin J-C (2000) Amphipods are good bioindicators of the impact of oil spills on soft-bottom macrobenthic communities. Mar Pollut Bull 40:1017-1027

Giangrande A, Licciano M, Musco L (2005) Polychaetes as environmental indicators revisited. Mar Pollut Bull 50:11531162

Gomez Gesteira JL, Dauvin J-C, Salvande Fraga M (2003) Taxonomic level for assessing oil spill effects on soft-bottom sublittoral communities. Mar Pollut Bull 46:562-572

Grassle JF, Maciolek NJ (1992) Deep-sea richness: regional and local diversity estimates from quantitative bottom samples. Am Nat 139:313-341

Gray JS, Poore GCB, Ugland KI, Wilson RS, Olsgard F, Johannessen Ø (1997) Coastal and deep-sea benthic diversities compared. Mar Ecol Prog Ser 159:97-103

Grémare A, Amouroux JM, Vetion G (1998) Long-term comparison of macrobenthos within the soft bottoms of the Bay of Banyulssur-mer (Northwestern Mediterranean Sea). J Sea Res 40:281302

Guille A (1971) Bionomie benthique du plateau continental de la côte catalane française IV-Densités, biomasses et variations saisonnières de la macrofaune. Vie et Milieu 22:93-158

Harrison S, Ross SJ, Lawton JH (1992) Beta diversity on geographic gradients in Britain. J Anim Ecol 61:151-158

Hurlbert SH (1971) The nonconcept of species diversity: a critique and alternative parameters. Ecology 52:577-586

Josefson AB, Jensen JN, AErtebjerg G (1993) The benthos community structure anomaly in the late 1970s and early 1980s-a result of a major food pulse? J Exp Mar Biol Ecol 172:31-45

Karakassis I (1995) S infinity: a new method for calculating macrobenthic species richness. Mar Ecol Prog Ser 120:299-303

Karakassis I, Eleftheriou A (1997) The continental shelf of Crete: structure of macrobenthic communities. Mar Ecol Prog Ser 160:185-196

Karakassis I, Machias A, Pitta P, Papadopoulou KN, Smith CJ, Apostolaki ET, Giannoulaki M, Koutsoubas D, Somarakis S (2006) Cross-community congruence of patterns in a marine 
ecosystem: do the parts reflect the whole? Mar Ecol Prog Ser 310:47-54

Kunin WE (1997) Sample shape, spatial scale and species counts: implications for reserve design. Biol Conserv 82:369-377

Labrune C, Amouroux JM, Sardá R, Dutrieux E, Thorin S, Rosenberg R, Grémare A (2006a) Characterization of the ecological quality of the coastal Gulf of Lions (NW Mediterranean). A comparative approach based on three biotic indices. Mar Pollut Bull 52:34-47

Labrune C, Grémare A, Amouroux J-M, Sardá R, Gil J, Taboada S (2006b) Diversity of polychaete fauna in the Gulf of Lions (NW Mediterranean). Vie et Milieu 56:315-326

Labrune C, Grémare A, Amouroux J-M, Sardá R, Gil J, Taboada S (2007) Assessment of soft-bottom polychaete assemblages in the Gulf of Lions (NW Mediterranean) based on a mesoscale survey. Estuar Coast Shelf Sci 71:133-147

Levin SA (1992) The problem of pattern and scale in ecology. Ecology 73:1943-1967

Mackie ASY, Oliver PG, Darbyshire T, Mortimer K (2005) Shallow marine benthic invertebrates of the Seychelles Plateau: high diversity in a tropical oligotrophic environment. Philos Trans $\mathrm{R}$ Soc Lond A 363:203-228

Magurran AE (2004) Measuring biological diversity, vol. Blackwell Science, Oxford

National Research Council (1995) Understanding marine biodiversity: a research agenda for a nation, vol. National Academy Press, Washington DC

Olsgard F, Somerfield PJ (2000) Surrogates in marine benthic investigations-which taxonomic unit to target? J Aquat Ecosyst Stress Recovery 7:25-42

Olsgard F, Somerfield PJ, Carr R (1997) Relationship between taxonomic resolution and data transformations in analyses of a macrobenthic community along an established pollution gradient. Mar Ecol Prog Ser 149:173-181

Olsgard F, Brattegard T, Holthe T (2003) Polychaetes as surrogates for marine biodiversity: lower taxonomic resolution and indicator groups. Biodivers Conserv 12:1033-1049

Pearson TH, Rosenberg R (1978) Macrobenthic succession in relation to organic enrichment and pollution of the marine environment. Ocean Mar Biol Ann Rev 16:229-311

Picard J (1965) Recherches qualitatives sur les biocénoses marines des substrats meubles dragables de la région marseillaise. Recueil des Travaux de la Station Marine d'Endoume 52:1-160

Pielou EC (1966) Species diversity and pattern diversity in the study of ecological succession. J Theor Biol 10:370-383

Probert PK, Grove SL (1998) Macrobenthic assemblages of the continental shelf and upper slope off the west coast of South Island, New Zealand. J R Soc NZ 28:259-280

Rhoads DC, Young DK (1970) The influence of deposit-feeding organisms on sediment stability and community trophic structure. J Mar Res 28:150-178

Riedl R (1983) Fauna und Flora des Mittelmeeres. Verlag Paul Parey, Hamburg und Berlin, p 836
Roberts RD, Gregory MR, Foster BA (1998) Developing an efficient macrofauna monitoring index from an impact study - a dredge spoil example. Mar Pollut Bull 36:231-235

Rosenberg R, Gray JS, Josefson AB, Pearson TH (1987) Petersen's benthic stations revisited. II. Is the Oslofjord and easternn Skagerrak enriched? J Exp Mar Biol Ecol 105:219-251

Rosenberg R, Nilsson H, Grémare A, Amouroux JM (2003) Effects of demersal trawling on marine sedimentary habitats analysed by sediment profile imagery. J Exp Mar Biol Ecol 285-286:465477

Rygg B (1985) Distribution of species along pollution-induced diversity gradients in benthic communities in Norwegian fjords. Mar Pollut Bull 16:469-474

Sardá R, Pinedo S, Grémare A, Taboada S (2000) Changes in the dynamics of shallow sandy-bottom assemblages due to sand extraction in the Catalan Western Mediterranean Sea. ICES J Mar Sci 57:1446-1453

Sardá R, Pinedo S, Grémare A, Taboada S (2001) Changes in the dynamics of shallow soft-bottom due to man-made disturbance processes in the Catalan Western Mediterranean Sea. ICES J Mar Sci 57:1446-1457

Shannon CE, Weaver W (1949) The mathematical theory of communication, vol. University of Illinois Press, Urbana

Shin PKS, Ellingsen KE (2004) Spatial patterns of soft-sediment benthic diversity in subtropical Hong Kong waters. Mar Ecol Prog Ser 276:25-35

Somerfield PJ, Clarke KR (1995) Taxonomic levels, in marine community studies, revisited. Mar Ecol Prog Ser 154:303-306

Tselepides A, Papadopoulou KN, Podaras D, Plaiti W, Koutsoubas D (2000) Macrobenthic community structure over continental margin of Crete (South Aegean Sea, NE Mediterranean). Prog Oceanogr 46:401-428

Ugland KI, Gray JS, Ellingsen KE (2003) The species-accumulation curve and estimation of species richness. J Anim Ecol 72:888897

Ugland KI, Gray JS, Lambshead PJD (2005) Species accumulation curves analysed by a class of null models discovered by Arrhenius. Oikos 108:263-274

Warwick RM (1988) The level of taxonomic discrimination required to detect pollution effects on marine benthic communities. Mar Pollut Bull 19:259-268

Warwick RM (1993) Environmental impact studies on marine communities: pragmatical considerations. Aust J Ecol 18:63-80

Warwick RM, Clarke KR (1993) Comparing the severity of disturbance: a meta-analysis of marine macrobenthic community data. Mar Ecol Prog Ser 92:221-231

Whittaker RH (1960) Vegetation of the Siskiyou Mountains, Oregon and California. Ecol Monogr 30:279-338

Whittaker RH (1972) Evolution and measurement of species diversity. Taxon 21:213-251 